\title{
Impact of innovation on economic growth of Sri Lanka: an empirical study
}

\author{
M.N.F. Washima \\ Faculty of Arts and Culture, South Eastern University of Sri Lanka.
}

\begin{abstract}
Innovation is one of the most important factor and main incentive for sustainable growth and economic development of a country. This researchaim to identify the impact of innovation and other macroeconomic variable on economic growth of Sri Lanka over the period of time 1978 to 2017. This research has usedOrdinary Least Square Model (OLS) to identify the relationship between the innovation and Gross Domestic Product. According to the results, Research and Development expenditure, Patten Applications for residents, Gross Domestic Product per Capita, and capital formation are statistically and significantly influenced on economic growth of Sri Lanka. But, there is negative relationship between the Gross Domestic Product and export, expenditure education and Foreign Direct Investment. Hence, this study concludes that effectiveness of innovation will lead to sustainable economic growth of Sri Lanka. This study suggests that higher expenditure on scientific research and development and vocational and technical education may promote the productivity through new technology and innovations. And also, Policy makers should focus on promoting the monetary policy and allocating recourse efficiently for the sustainable growth of the country.
\end{abstract}

Keywords - Economic growth, gross domestic product, innovation, $r \& d$ expenditure

\section{Introduction}

Innovation is one of the most important factor for sustainable growth and economic development of a country. Definition of the innovation is varied person to person. In the view of customers, innovation refers products with better quality and better service.
From the aspect of business, innovation is defined as sustainable growth and development and earning more profit. Employees means new and more interesting job which gives higher salaries. Further, Organization for Economic Co-operation and Development (OECD) refers, "Innovation is production or Adoption, 
assimilation and exploitation of a valueadded novelty in economic and social spheres; renewal and enlargement of products, services and markets: development of new methods of production and establishment of new management systems. It is both a process and an outcomes". Hence, simply we can say, innovation is transforming the new idea and knowledge into new product and services.

Globally innovation is measured by the Global Innovation Index (GII). GII rank the countries annually according to the country's capacity for success in innovation. The GlobalInnovation Index is computed by the two subindices such as the Innovation Input Sub-Index and the Innovation Output Sub-Index.

Gross Domestic Product (GDP) is used to measure the economic growth of a country. GDP is measurement of a countries output with in period of time. In order to promote the economic growth of country, a country increase the number of inputs or productivtity of inputs. Here, productivity is increased by the new ideas and innovation.

Therefore, in the modern economy, innovation is essential for value creation, growth and employment of an economy and its processes take place at the various level of enterprise, regional and national (Shqipe Gerguri and Veland Ramadani, 2010). And also, innovation leads to new businesses and to increase competitiveness of existing enterprises. Importantly, it helps to a country to achieve its goal by increasing output through improving productivity of inputs which is only possible by innovating new products or production process.

Although, innovation of new products are critical to a country's sustainable growth and higher standard of living. But, nowadays, developed countries are spending on research and development more than the developing countries and underdeveloped countries (Shukla, 2017).That's why developed countries became a leader country. Even in Sri Lanka, it spend on R \& D expenditure very less amount. So, innovation seems an important driver of long-term productivity and sustainable economic growth of a country.

Nowadays, Sri Lanka tries to move from lower middle income country to a higher middle income country within the next two decades. Nevertheless, Sri Lanka want to consider about recovery from the middle 
income country trap.Because, Sri Lanka is one of the developing and agriculture base country. Its current productions are based on simple technology. So, the Economic Complexity Index compiled by Harvard University and Massachusetts Institute of Technology has ranked Sri Lanka as a simple product producing country since 1995. Accordingly, for all these years, about 98 percent of Sri Lanka's exports has been based on simple technology (Wijewardene, 2015). Even though, Sri Lanka will be able to boost its overall economy through enhanced focus on innovation. Because, according to the National Science \& Technology Commission (NASTEC), there exists a correlation between investing in research and development, and higher economic growth, potentially doubling GDP growth.

Gross Innovation Index (GII) provides the innovation performance of 27 countries around the world. According to the GII report of Sri Lanka, in 2015, 2016, 2017 and 2018 performance of innovation was as $30.79,28.92,29.90$ and 28.66 respectively. Furthermore, the average values for Sri Lanka during the period from 2011 to 2018 was 29.66 points only. Specially, in the 2018 minimum of 28.7 points are calculated during this period. So, this data shows that innovation performance of the country declines (Cornell University, INSEAD, and the WIPO, 2018). In 2018 Sri Lanka was ranked in 88th place in world innovation index. Hence, this reflects Sri Lanka's poor performance and expenditure on human capital and research and development, weak and unstable political and regulatory environment.

Furthermore, Even Sri Lanka as a developing country, in 1975 it allocated 0.4 percent as share of total GDP on research and development. But, after that it is showing diminishing trend on the spending of research and development. $0.3,0.2,0.18$ and 0.11 percent are only allocated on the research and development in 1979, 1983, 1996 and 2017 respectively. Consequently, spending on research and development that directly affect the county's sustainable economic growth. So, this study aimed to find the impact of innovation on economic growth of Sri Lanka.

\section{Literature Review}

Traditional growth theory of Joseph Alois Schumpeter (1911) shows that development is depend on the carrying out of new combinations for which possibilities exit in the stationary state. So, here new combination come in the form of innovation. 
Nathan Rosenberg (2004) identified the reasons to considertechnological innovation as a major force in economic growth in America. The impact of a technological innovation will generally depend on its inventors and on the creativity of the eventual users of the new technology. And, he found that technological innovation affect the tourism sector also. due to the innovation, tourism become more profitable sector.

Sushma Shukla (2017), investigated the role of innovation on economic growth of India using Multiple Lenier Model. This study identified that $R \& D$ exoanditure, education spending foreign direct investment and number of patent applications filed had a negative impact on economic growth of India. So, this findings are raised the questions regarding their efficient resource allocation.

Niranjala and Wei Jianguo (2015), investigated that the relationship between innovation and economic growth. This reseach is discovered the long run relationship between economic growth and other economic variables using Augmented Dickey-Fuller (ADF) unit root test and Johansen's test of cointergration and innovation is positively influence on economic growth.
Manoj Joshi (n.d.), identified that the most important determinant of innovation is the innovative effort which is measured by the R\&D expenditure. The level of interaction, Human Capital and entrepreneurial spirit also determine the innovation. Shqipe Gerguri and Veland Ramadani (2010, found the impact of innovation has on economic growthon the basis of all the characteristics of innovation, good basis for a proper usage of innovation and ways of transforming.

Walid Hadhri, Rigas Arvanitis et Hatem M'Henni (2016), innovation activities in small and open economies: the lebanese business sector is determined by the age and size of the firm, exports, competition pressure, $\mathrm{R} \& \mathrm{D}$, partnership and technology transfer. According to the findings, that show no any statistical relationship between the age of firm and innovation capabilities. Innovation had the non-significant relationship with the exports and competition pressure. Size of the firm, $R \& D$, partnership and technology transfer had the positive relationship on innovation capabilities.

\section{Objectives of the Study}

The main objective of this research is to examine the impact of innovation on economic growth in Sri Lanka. Specifically, this research is designed to: 
1. Test the impact of the innovation and its determinants on economic growth in Sri Lanka.

2. Suggest appropriate and efficient policy recommendations that can help to sustainable growth of Sri Lanka.

\section{Research Methodology}

\subsection{Data Collection}

This study is conducted in quantitative and qualitative method. Itis explained through secondary data which are collected from Sri Lanka Science, Technology and Innovation Statistical Handbook, GII report of Cornell University, INSEAD and the WIPO Annual Report of Central Bank of Sri Lanka, Journals, research articles and a popular statistics database website called Knoema. The study is conducted with time series data from 1978to 2017. The collected data is analyzed in the Ordinary least squares (OLS) method using Statistical Package for the Social Sciences (SPSS).

\subsection{Model Specification}

The multiple regression model is used to observe the relationship between the various independent variables and a dependent variable. The dependent variable of this study is Gross Domestic Products and independent variables are, R\&D Expenditure, Patent Applications among Residents, Unemployment Rate, and Expenditure on Education, GDP Per Capita, Net Foreign Direct Investment, Export Revenue, and Capital Formation. Model Specific as follow:

$\mathrm{GDPt}=\beta 0+\beta 1 \mathrm{R} \& \mathrm{D} \_\mathrm{EXPt}+$ $\beta 2 \mathrm{PAT}_{-} \mathrm{APPt}+\beta 3 \mathrm{UNEMPt}$ $+\beta 4 \mathrm{EXP} \_\mathrm{EDUt}+\beta 5 \mathrm{GDP} \_\mathrm{PCt}+$ $\beta 6 \mathrm{FDIt}+\beta 7 \mathrm{EXt}+\beta 8 \mathrm{CAPt}+\mathrm{Ut}$

GDP: Gross domestic product has used as a proxy of economic of an economy in givenperiod of time.This is the dependent variable of this study.

R\&D_EXPAN: Research and Development Expenditure (Percentage of total GDP) is proxy of economic and innovation growth of an economy. Sri Lanka As a developing country if R \& D expenditure rises GDP also rise. Therefore, this should be positive.

PAT_APP: Patent Applications among Residents provides protection for innovation.

UNEMP: Unemployment Rate (Percentage of total GDP) is considered as control variable. Further, it should be inversely related with both innovation 
and economic growth. Because, higher unemployment affect the production of a country.

EXPAN_EDU: Expenditure on Education (Percentage of total GNI) is a proxy for human capital in an economy. As spending on education increases, it increases level of human capital. So, it leads towards new innovation.

GDP_PC: GDP Per Capita is measurement of standard of living. GDP growth rate should be positive correlation with the GDP per capita.

FDI: Net Foreign Direct Investment is represented the interest on foreign investment (Percentage of total GDP).

CAP: Capital Formation (Percentage of total GDP) is a proxy of capital investment. FDI and Capital formation provide the favourable environment in production through the higher investment. Hence, this both directly correlated with the GDP and innovation. EX: Export Revenue (Percentage of total GDP) is proxy of open trade.

Ut : error term

\section{Result and Discussion}

To identify the connection between GDP and independent variables. Following multiple regression models are used. Namely, Linear-Linear, Linear-Log, Log-Linear and Log-Log models. The best model is selected according to the various statistics which shown in table 1 . According to the table 1, the Adjusted $\mathrm{R} 2$ is critically lower in the Linear- Log model (.640). The linear - Linear model has the higher R2, the value is .825 than the Log - Linear and Log - Log models which havethe R2 as .757 and .790 respectively. F value of Linear - Linear model shows the highest value of 22.753 .

According to the P value, Linear- Linear model is significant at a 1 percentage confidence interval. Hence, it shows the dependent variable has higher influence on the independent variable. So, Linear - Linear model was taken as the best model to measure the relationship between the innovation and economic growth in Sri Lanka.

$\mathrm{GDPt}=\beta 0+\beta 1 \mathrm{R} \& \mathrm{D} \_\mathrm{EXPt}+$ $\beta 2 \mathrm{PAT}_{-} \mathrm{APPt}+\beta 3 \mathrm{UNEMPt}$ $+\beta 4 \mathrm{EXP} E \mathrm{EDUt}+\beta 5 \mathrm{GDP} \_\mathrm{PCt}+$ $\beta 6 \mathrm{FDIt}+\beta 7 \mathrm{EXt}+\beta 8 \mathrm{CAPt}+\mathrm{Ut}$

According to the table 1. the correlation matrix tests the multicollinearity between two independent variables. This matrix explains no multicolineratiny between the any twoindependent variable. The result describe that there is strong positive 
Table 1. Correlation Matrix of the Variables

\begin{tabular}{|c|c|c|c|c|c|c|c|c|c|}
\hline & GDP & $\begin{array}{l}\mathrm{R} \& \mathrm{D}_{-} \\
\mathrm{EXP}\end{array}$ & $\begin{array}{l}\text { PAT }_{-} \\
\text {APP }\end{array}$ & UNEMP & $\begin{array}{l}\mathrm{EXP}_{-} \\
\mathrm{EDU}\end{array}$ & $\begin{array}{l}\mathrm{GDP}_{-} \\
\mathrm{PC}\end{array}$ & FDI & EX & CAP \\
\hline GDP & 1.000 & & & & & & & & \\
\hline $\begin{array}{l}\mathrm{R} \& \mathrm{D} \\
\mathrm{EXP}\end{array}$ & .030 & 1.000 & & & & & & & \\
\hline $\begin{array}{l}\mathrm{PAT}_{-} \\
\mathrm{APP}\end{array}$ & .286 & -.659 & 1.000 & & & & & & \\
\hline UNEMP & -.256 & .432 & -.808 & 1.000 & & & & & \\
\hline $\begin{array}{l}\mathrm{EXP}_{-} \\
\mathrm{EDU}\end{array}$ & -.270 & .432 & -.660 & .559 & 1.000 & & & & \\
\hline GDP_PC & .855 &.-017 & .182 & -.218 & -.144 & 1.000 & & & \\
\hline FDI & .326 &.-245 & .319 & -.258 & .034 & .372 & 1.000 & & \\
\hline EX & -.130 & .431 & -.521 & -.625 & -.570 & .266 & .325 & 1.000 & \\
\hline CAP & .489 &.-304 & .584 & .442 & .779 & .028 & .140 & -.483 & 1.000 \\
\hline
\end{tabular}

Source: Computed in SPSS

correlation of GDP with GDP_PC. Association of UNEMP with There is weak positive association of EXP_EDU is strong and positive as well GDP with R\&D_EXP, PAT_APP, FDI and CAP. That above table shows that there is weak negative correlation of GDP with UNEMP,EXP_EDU and EX. as with CAP weak and positive. There is strong negative association of UNEMP with EX and weak negative with GDP_PC and FDI. But, correlation of The correlation between R\&D_EXP and PAT_APP is negatively strong. There is GDP_PC is weak and positive with FDI, EX and CAP.

weak negative correlation between R\&D EXP and GDP PC, FDI and CAP.

The results of the estimated model There is weak positive assication of PAT_APP with UNEMP, EXP_EDU and EX. There is relatively strong negative association of PAT_APP with UNEMP, EXP_EDU and EX. Association of PAT_APP with CAP is strong positive. There is weak positive correlation of Pat_APP with GDP_PC and EX. which explains that specified model performed very well in terms of FStatistics. The results describe that model is highly significant. R2 the coefficient of determination explains how muchlinear relationship has the dependent variable with independent variables. The value of $\mathrm{R} 2$ is 0.825 , which explains that 82 percent variation 
Table 2. Model Summary

\begin{tabular}{lrrrrr}
\hline Model & R & R Square & Adjusted R Square & $\begin{array}{c}\text { Std. Error of the } \\
\text { Estimate }\end{array}$ & Durbin-Watson \\
\hline 1 & $.929^{\mathrm{a}}$ & .863 & .825 & .81341 & 2.301 \\
\hline
\end{tabular}

Table 2. Model Summary

Source: Computed in SPSS

Table 3. ANOVA

\begin{tabular}{rrrrrrr}
\hline Model & & Sum of Squares & df & Mean Square & F & \multicolumn{1}{c}{ Sig. } \\
\hline & Regression & 120.435 & 8 & 15.054 & 22.753 & $.000^{\mathrm{b}}$ \\
1 & Residual & 19.188 & 29 & .662 & & \\
& Total & 139.622 & 37 & & & \\
\hline
\end{tabular}

Source: Computed in SPSS

Table 4. Coefficients

\begin{tabular}{llll}
\hline Predictor & Coefficient & T Value & P Value \\
\hline Constant & -5.897 & -2.342 & 0.26 \\
R\&D_EXP & 10.006 & 2.6 & 0.15 \\
PAT_APP & .008 & 2.221 & 0.34 \\
UNEMP & .184 & 2.483 & 0.19 \\
EXP_EDU & -.019 & -0.27 & .978 \\
GDP_PC & .796 & 10.269 & .000 \\
FDI & -.146 & -.442 & .662 \\
EX & -0.16 & -.394 & .696 \\
CAP & .162 & 3.290 & .003 \\
\hline
\end{tabular}

Source: Computed in SPSS 
in the GDP is explained by the independent variables. The Durbin Watson statistics is 2.301 which indicates that there is no problem of autocorrelation in this Linear - Linear model.

The model shows that there is a significant and positive impact of $R \& D$ expenditure, patent application among residents, GDP per capita and capital formation. This explains that increase in R\&D expenditure, patent application among residents, GDP per capita and capital formation causes gross domestic product to increase. This result means that one percent changes in $R \& D$ expenditure, patent application among residents, GDP per capita and capital formation will bring about 10.0, $0.008,0.796$ and 0.162 percentage changes in GDP.Hence, Sri Lanka can increase the production level of country through increase in expenditure on R \& $\mathrm{D}$ expenditure. Because, it promote the productivity and efficiency of producers and promote the production process. As well as, through the new innovations and technologies, producers can produce the more production within low cost and it helps to save the time of producers.

GDP per capita also show the positive relationship with GDP. So, if the GDP per capita increases, that leads to the higher standard of living. Eventually, it helps to the economic development of a country. But, in developing countries like Sri Lanka, they cannot increase the GDP per capita at the same or higher proportion than the population growth.That's why, even GDP per capita rises, country is facing the problem in reducing poverty. Further, Large amount of the capital formation induce the investment on production and leads to the economic growth.

Unemployment significantly and positively related with the GDP. But, according to assumption it supposed to be inversely related with the GDP. That seems unrealistic. Because, while unemployment rises, economic growth falls due to the fall in production of a country. Unemployment means the country cannot utilize its whole resource efficiently. Therefore, some resources are in unemployment condition.

There is negative impact of expenditure on education, foreign direct investment inflows and export on GDP. As well as, that variables are not significant in this model. This shows that one percent change in expenditure on education, net foreign direct investment inflows and export will bring about $0.019,0.146$ and 0.016 percentage changes in GDP in inverse direction. That means if the Sri Lankan economic growth will increase, 
it will decrease the expenditure on education, foreign direct investment inflows and export. This also seems unrealistic and surprising. This all variables supposed to be positively related with GDP. Because, large amount of expenditure on education and foreign direct investment promote the sustainable growth of Sri Lanka. Sri Lanka is one of the developing country. So, expenditure on education transform the people as efficient human capital and supports to sustainable growth of country.

Moreover, high foreign direct investment rise the investment opportunities. But, in Sri Lanka FDI inflows are not properly working in promoting economic growth of a country. Because, most of the FDI inflows in Sri Lanka depend on developing the infrastructure facilities of country, especially in road development.

Hence, this study found that innovation and economic growth has a direct impact. So, through the increase on innovation, a country can reach its goal that sustainable economic growth and development.

\section{Conclusion}

Nowadays, Innovation play a vital role in increasing economic growth and development of country. Because, innovation leads to increase the productivity of the inputs by the new ideas. As well as innovation is not only contribute to increase the economic growth but also to formulate the new business and to create new and better employment opportunities with higher earning.

According to the model results, $R \& D$ expenditure, Patten Applications for residents, GDP per Capita, and capital formation are statistically and significantly influenced on economic growth of Sri Lanka. But, there is negative relationship between the GDP and export, expenditure education and FDI. Even though, this negative relationship is not acceptable. Because, it means that increase in the export, expenditure on education and FDI decrease the GDP of Sri Lanka. As well as, this result describes that positive relationship between the GDP and unemployment. Moreover, Sri Lanka's some inefficient resource allocation and simple technology may be the reasons for the negative relationship.

Hence, Sri Lanka as a lower middle income country, Sri Lanka want to try to increase the innovation, technology and productivity to increase the sustainable economic growth and to move to higher middle income trap. As well as, Sri 
Lanka want to increase the $\mathrm{R} \& \mathrm{D}$ expenditure to promote the economic growth of the Sri Lanka by the new business and higher productivity. Further, efficient resource allocation and expenditure on new and systematic education which have capacity and capability to compete with the modern job market.This study suggests that higher expenditure on scientific research and development and vocational and technical education may promote the productivity through new technology and innovations. And also, Policy makers should focus on promoting the monetary policy and allocating recourse efficiently for the sustainable growth of the country.

Moreover, this study noted that there were some limitations. Main limitation was unavailability of the data. There are many other variables, canbe included in the study, are prevented due to the lack of availability of the data.

\section{Acknowledgement}

I am grateful to all the persons who supported for their valuable comments and suggestions to conduct this research.

\section{References}

Bashir, H. A., \& Akhthar, A. (2016). The role of innovative entrepreneurship in economic development: A study of G20 countries. Management Studies and Economic Systems, 3(2), 91-100. Retrieved from http://www.msaes.org.

Eggink, M. E. (2011). The role of innovation in Economic Development (Published doctoral dissertation). University of South Africa. Retrived from http://www. uir.unisa.ac.za.

Fagerbeerg, J., Srholec, M., \& Verspagen, B. (2010). The role of Innovation in Development. Review of Economics and Insititutions, Vol.1 - NO.2, 1-29. Retrieved from http://www. researcggate.net.

Gerguri, S., \& Ramadani, V. (2010). The impacts of innovation into the economic growth. Retrieved from: Munich Personal RePEc Archive. 1-22. Hadhri, W., Arvanties,. \& M'Henni, H. (2016). Determinants of innovation activities in small and open economies: The Lebanese business sector. Journal of Innovation Economics and Management. n, 21, 77-107

Jinghan, M. I. (1993). The economics of development and planning. Konark Publishers PVT Ltd.

Niranjal, S.A.U., \& Jiango, W. (2015). The relationship between innovation and economic growth in Sri Lanka. Journal of Economics and Sustainable Development, Vol.6, No.22, 74-81. 
Pece, A. M., Simona, O.E., \&Salisteanu, F. (2015). Innovation and economic growth: An empirical analysis for CEE countries. Procedia Economics and Finance, 26 (2015), 461-467. Retrieved from http://www. seciecedirect.com.

Petrariu, I. R., Bumbac, R., \& Ciobanu, R. (2013). Innovation: a path of competitiveness and economic growth. The case of CEE countries. Theoretical and Applied Economics . Vol XX (2013), No.5 (582), 15-26. Retrieved from http://www. store.ectap.ro.

Rosenberg, N. (2004). Innovation and economic growth. Organization for Economic Co-operation and Development. Retrieved from: www.oecd.org.

Shanmuganathan, A. (2018). Innovation in

Sri Lanka. Retrieved from http://www.researcggate.net.
Shukla, S. (2017). Innovation and economic growth: A case study of India. Humanities and Social Science Review, 5(2), 64-70.

Szirmai, A., Naude, W., \& Goedhuya, M. Entrepreneurship, Innovation and Economic Development: An overview. Retrieved from: Semantic Scholar Organization. Retrieved from http://www.pdfs.sementi cscholar.org Uchechukwu, U., Faga, H. P., \& Obeikwe, A. D. (2016). The role of innovation in the economic development of Nigeria. International Journal of Innovative Research \& Development. Vol.5, Issue. 6, 500-518. Retrieved from http://www.researcggate.net. 